\title{
The Effect of Leverage, Profitability, Liquidity, and Asset Growth on Corporate Value of Consumption Goods Sectors Listed in Idonesia Stock Exchange in 2015-2018
}

\author{
Naelly ${ }^{1}$ \\ Mercu Buana University, Jakarta
}

\begin{abstract}
The value of companies in the consumer goods sector listed on the IDX in the 2015-2018 period tends to fluctuate. Company value can reflect the prosperity of a company. The value of the company is also a consideration for investors to invest. One indicator used to measure the high and low values of a company is to look at the company's Price to Book Value (PBV). By analyzing a company's financial statements, it can be seen whether the company has a high or low investment value. The financial ratios reflected in the financial statements are thought to affect the value of the company. This study intends to examine the effect of Debt Equity Ratio (DER), Return on Assets (ROA), Current Ratio (CR), and Asset Growth on Price to Book Value (PBV). The sampling technique used purposive sampling and obtained a sample of 20 consumer goods sector companies listed on the Indonesia Stock Exchange in the 2015-2018 period. The research method uses panel data regression analysis. From the results of the study concluded that DER, ROA, and Asset Growth had a positive and significant effect on PBV, whereas CR had a negative and not significant effect on PBV.
\end{abstract}

Keywords:- Company value, Price to Book Value (PBV), Debt to Equity Ratio (DER), Return on Assets (ROA), Current Ratio (CR), Asset Growth.

\section{INTRODUCTION}

The company was established to have goals, both short and long term goals. The short-term goal is to make a profit, while the long-term goal is to achieve prosperity, both for owners, shareholders and employees.

Company value is the market value of the company's debt securities and outstanding equity (Keown, 2014). Company value is very important, because it is a reflection of company performance that can affect investor perceptions of the company.

The Indonesia Stock Exchange (IDX) or the Indonesia Stock Exchange (IDX) is a party that organizes and provides a system as well as a means to bring together the sale and purchase offers of other parties with the aim of trading securities between them. IDX is a merged stock exchange from the Jakarta Stock Exchange (BEJ) with the

\author{
Matrodji Mustafa ${ }^{2}$ \\ Mercu Buana University, Jakarta
}

Surabaya Stock Exchange (BES). For the sake of operational and transaction effectiveness, As stated in the Indonesian economic report issued by Bank Indonesia, it states that the consumer goods sector, especially food and beverages, is an influential sector in moving the economy.

PBV of the consumer goods sector fluctuated during the 2015-2018 period, where there was a drastic decline in 2016 when compared to conditions in 2015, but again increased sharply in 2017, then again fell in 2018 but not significant. This proves that the company value of the consumer goods sector is still quite stable. Investors will certainly be interested in investing their money to buy shares of high value companies that tend to be stable. On the contrary, fluctuations in the average financial ratios in the consumer goods sector listed on the IDX in the 20152018 period. The financial ratio does not fully affect the value of the company, where a high ROA does not necessarily increase the value of the company, and vice versa low ROA can increase company value.Leverage ratio or the solvency ratio that compares the company's total debt burden to its assets or equity. In general, the leverage ratio serves to measure the company's ability to meet its financial obligations both in the short and long term. By looking at the leverage ratio, investors can see the company's capital structure.Capital structure is the proportion of funding with corporate debt. Thus, debt is an element of the capital structure that is the key to improving profitability and company performance. In this study, researchers chose Debt to Equity Ratio (DER) as the leverage ratio. Mogdiliani and Miller (1963) stated that the higher the proportion of debt, the higher the value of the company.

\section{LITERATURE REVIEW}

\section{A. Capital Structure Theory}

Capital structure is the main topic contained in finance, both discussed as subtopics in corporate finance and in investment decisions. Capital structure is a balance or comparison between foreign capital (long term) and own capital. Capital structure is an important issue for a company, because the good or bad capital structure will have a direct effect on the company's financial position (Riyanto, 2011). 


\section{B. Signaling Theory}

Signal theory is all about how a company should give signals to users of financial statements, in the form of information about what has been done by company management that provides instructions for investors about how management views the company's prospects. One of them is by paying a relatively large amount of cash dividends. Large dividends will indeed tend to reduce the amount of capital expenditure so that it may disrupt the company's growth. But because of good performance, the company can still generate profits even still growing (Arifin, 2005: 12).

\section{Definition of Company Value}

According to Timbuleng (2015) the value of a company can be seen from its stock price. Stock prices are formed at the request and offer of investors, so that the stock price can be used as a proxy for the company's value. High stock prices make the value of the company is also high. High company value will make the market believe not only in the company's current performance but also in the company's future prospects.

\section{Price to Book Value (PBV) Theory}

Price to book value (PBV) is a calculation or comparison between market value and book value of a stock. With this PBV ratio, investors can know firsthand how many times the book value of a stock is valued at market value. PBV ratio can provide a picture of potential stock price movements so from this picture, indirectly the PBV ratio also has an effect on stock prices. PBV is a market value (price / market value) divided by book value (price / book value).

\section{E. Definition of Capital Structure}

Leverage ratio or more familiarly called the leverage ratio or solvency ratio is a financial ratio that shows the level of debt that has been issued by a business entity or business. The leverage ratio is also called the solvency ratio can be understood as a financial ratio that measures the ability of a company to meet its obligations or long-term debt.

Capital structure is the ratio between debt and equity. Whereas own capital can be divided into retained earnings and can also be with the ownership of company ownership.

Capital structure is permanent financing consisting of long-term debt, preferred shares, and shareholder capital. The decision of funding regarding the capital structure really must be considered by the company, because the structure of determining the company will affect the value of the company. This means that the greater the capital structure, the value of the company will also increase.

\section{F. Profitability}

Profitability is the main ratio in all financial statements, because the company's main goal is to make a profit. The profit ratio will be used to measure the effectiveness of the company's operations so as to produce profits in the company. Without profit, it will be very difficult for companies to attract capital from outside.

Company profitability is one way to assess accurately the extent of the returns to be obtained from its investment activities. The better growth of a company's profitability means the prospect of the company in the future is considered better, meaning that the value of the company will also be assessed better in the eyes of investors. The higher the profitability means the better, because the prosperity of the company owner increases with the higher profitability.

\section{G. Liquidity}

Liquidity is the company's ability to meet its shortterm obligations. Liquidity is one of the factors that determine the success or failure of a company. Provision of cash needs and resources to meet these needs determine the extent to which the company is at risk. Two liquidity ratios are commonly used, namely the current ratio and quick ratio.

\section{H. Asset Growth}

Asset Growth is the growth of total assets owned by a company from year to year. The total assets owned by the company reflect the strength of the company itself. An increase in assets from year to year proves that the company is in a developing state or even in the category of an established company. Company growth is expressed as a change (decrease or increase) in total current assets compared to changes in total past assets.

\section{THEORETICAL FRAMEWORK}

This study uses Debt to Equity Ratio, Return on Asset, Current Ratio, and Asset Growth variables as independent variables that affect the value of the company as measured by PBV.

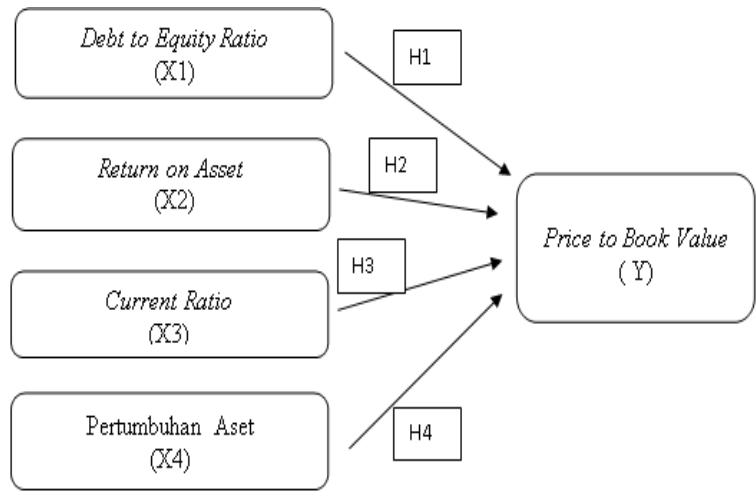

Fig 1:- Theoretical Framework

\section{Research Hypothesis}

H1: DER has a positive effect on firm value

$\mathrm{H} 2$ : ROA has a positive effect on Company Value

H3: Current Ratio has a positive effect on firm value.

H4: Asset Growth has a positive effect on firm value. 


\section{SAMPLES AND POPULATIONS}

The population used as material for this study were all companies in the consumer goods sector listed on the IDX as many as 57 companies. While the sample used is the following criteria:

The consumption goods sector companies listed on the Indonesia Stock Exchange in the period 2015-2018 were 57 companies.

$>$ The consumption goods sector companies that have complete financial statements and can be accessed in 2015-2018 are 20 companies in the consumer goods sector.

$>$ Consumer goods sector companies that have never been delisted from the IDX during the 2015-2018 period.

$>$ Companies that have PBV values above 1 (positive).

From the criteria above, 20 companies were obtained with a study period of 4 years, so that 80 observations were obtained.

\section{METHOD OF COLLECTING DATA}

Data collection methods used are:

The documentation method, which is collecting, recording and reviewing secondary data in the form of financial statements of consumer goods sector companies listed on the Indonesia Stock Exchange in the period 2015 - 2018.

$>$ Literature study methods, namely studying, exploring, and studying literature literature in the form of journals and other sources related to research. With the documentation method and literature study methods.

\section{DATA ANALYSIS METHOD}

This study uses an approachPanel Data Regression Analysis. Panel data is a combination of cross section and time series. The panel data regression model can be formulated as follows:

Yit $=\alpha+\beta$ Xit $+\varepsilon i t ; i=1,2, \ldots, N ; t=1,2, \ldots \mathrm{T}$

Information:

$\mathrm{N} \quad$ : Number of observations

$\mathrm{T} \quad$ : Amount of time

$\mathrm{N} \times \mathrm{T}:$ the amount of panel data

There are three approaches in making panel data regression

There are three approaches in making panel data regression.

\section{Common Effect Model}

Ordinary Least Square (OLS) or the least squares technique for estimating panel data models. The regression equation for type models is as follows:

$\mathrm{Yi}, \mathrm{t}=\alpha+\beta \mathrm{Xi}, \mathrm{t}+\varepsilon \mathrm{i}, \mathrm{t}$

for $\mathrm{i}=1,2, . ., \mathrm{N}$ and $\mathrm{t}=1,2, \ldots, \mathrm{T}$, where $\mathrm{N}$ is the number of units / individual cross sections and $\mathrm{T}$ is the number of time periods.

\section{Fixed Effect Model}

In this approach, the panel data model has intercepts that may change for each individual and time, where each cross section unit is fixed in time series. The model is as follows:

Yit $=\alpha+\beta$ Xit $+\gamma 2 \mathrm{~W} 2 \mathrm{t}+\gamma 3 \mathrm{~W} 3 \mathrm{t}+\ldots+\gamma \mathrm{NWNT}+\sigma 2 \mathrm{Zit}+$ $\sigma 3 \mathrm{Zi} 3+\ldots+\sigma \mathrm{TZiT}+$ Eit

Where :

Yit : the dependent variable for the i-th individual and time to $\mathrm{t}$

Xit : independent variable for the $\mathrm{i}$-th individual and $\mathrm{t}-$ th time

Wit : is a dummy variable where Wit = 1 for individuals $\mathrm{i}, \mathrm{i}=1,2, \ldots \mathrm{N}$ and 0 for the others

Zit $\quad$ : is a dummy variable where $\mathrm{Zit}=1$ for periods $\mathrm{t}, \mathrm{t}$ $=1.2, \ldots \mathrm{T}$ and 0 for others

\section{$>$ Random Effect}

In this method differences between time and between individuals are accommodated through errors. This research uses the Generalized Least Square (GLS) method. The degree of freedom is not necessary to estimate the crosssectional $\mathrm{N}$ intercept.

The equation of the random effect approach is as follows:

Yit $=\alpha+\beta$ Xit + Eit; $\varepsilon$ it $=\mathrm{Ui}+\mathrm{Vt}+\mathrm{Wit}$

Where :

Ui : cross section error

$\mathrm{Vt} \quad$ : time series error

Wit : error combined

\section{RESULTS AND DISCUSSION}

The data used in this study is panel data, which is a combination of time series data and cross section data. Time series data per year for the period 2014 to 2018 to test four independent variables (Debt to Equity Ratio (DER), Return on Assets (RoA), Current Ratio (CR), and Growth , on the dependent variable (dependent), namely Price to Book Value (PBV). 
Descriptive Statistical Analysis

Here is a table of data processing results for statistical analysis:

\begin{tabular}{|c|c|c|c|c|c|}
\hline & PBV_Y_ & DER_X1_ & ROA_X2_ & CR_X3_ & AG_X4_ \\
\hline The mean & 8.816563 & 0.828375 & 13,43025 & 300,8504 & 9.801125 \\
\hline Median & 4.055000 & 0.615000 & 10,55500 & 237.5650 & 8.300000 \\
\hline Maximum & 82.44000 & $3,600,000$ & 52.67000 & 927.6500 & 56.17000 \\
\hline Minimum & 1.050000 & 0.070000 & -5.670000 & 58,20000 & -10.52000 \\
\hline Std. Dev & 15,08939 & 0.702596 & 11.24902 & 210.4394 & 11,32941 \\
\hline Skewness & 3.233684 & 1,683990 & 1.360190 & 1.183993 & 1.480552 \\
\hline Kurtosis & 13.28694 & 6.124294 & 4.939029 & 3.682943 & 6.503012 \\
\hline Jarque-Bera & 492.1601 & 70,34837 & 37,20099 & 20.24591 & 70,13078 \\
\hline Probability & 0.000000 & 0.000000 & 0.000000 & 0.000040 & 0.000000 \\
\hline Sum & & & & & \\
\hline Sum Sq. Dev & 17987.48 & 38.99769 & 9996,694 & 3498495. & 10140.08 \\
\hline Observations & 80 & & & & 8 \\
\hline
\end{tabular}

Table 1:- Descriptive Statistics of Research Variables

\begin{tabular}{|l|c|c|c|c|c|}
\hline & Explan & 2015 & 2016 & 2017 & 2018 \\
\hline PBV & The mean & 9.16 & 7.48 & 9.65 & 8.97 \\
\hline & Median & 4.00 & 4.37 & 4.15 & 3.83 \\
\hline & Minimum & 1.05 & 1.40 & 1.28 & 1.17 \\
\hline & Maximum & 58.48 & 46.67 & 82.44 & 69.20 \\
\hline
\end{tabular}

Table 2:- Descriptive Statistics of PBV Data

Price to Book Value (PBV) is a comparison between the market value of shares with the book value of shares. Descriptive data in the table is displayed in decimal form. Based on the table, the minimum PBV value for 2015 is owned by PT. Indofood Sukses Makmur, Tbk., In 2016 was owned by PT. Tri Banyan Tirta, Tbk., In 2017 is owned by PT. Akasha Wira Internasional, Tbk., And in 2018 owned by PT. Tempo Scan Pacific, Tbk. Each year there are companies that have the smallest PBV value compared to other companies. The maximum value of PBV in 2015, 2016, 2017 is owned by PT. Unilever Indonesia, Tbk., While for 2018 it is owned by PT. Multi Bintang Indonesia, Tbk. Each year there are companies that have the highest PBV value compared to other companies.

\begin{tabular}{|c|c|c|c|c|c|}
\hline & Explan & 2015 & 2016 & 2017 & 2018 \\
\hline DER & The mean & 0.85 & 0.80 & 0.78 & 0.89 \\
\hline & Median & 0.71 & 0.65 & 0.58 & 0.59 \\
\hline & Minimum & 0.07 & 0.08 & 0.08 & 0.18 \\
\hline & Maximum & 3.03 & 2.56 & 2.65 & 3.60 \\
\hline & $\begin{array}{c}\text { Std. } \\
\text { Deviation }\end{array}$ & 0.74 & 0.61 & 0.65 & 0.84 \\
\hline
\end{tabular}

Table 3:- Descriptive Statistics of DER Data
Debt to Equity Ratio (DER) is a comparison between the value of debt with the value of equity. Descriptive data in the table is displayed in decimal form. Based on the table, the minimum value of DER in 2015, 2016 and 2017 is owned by PT. Sido Muncul, Tbk. Herbal Medicine and Pharmaceutical Industry, in 2018, is owned by PT. Delta Djakarta, Tbk. Each year there are companies that have the smallest DER value compared to other companies.

\begin{tabular}{|c|c|c|c|c|c|}
\hline & Explan & 2015 & 2016 & 2017 & 2018 \\
\hline ROA & The mean & 14.19 & 14.55 & 13.87 & 11.12 \\
\hline & Median & 11.02 & 10.68 & 11.07 & 8.21 \\
\hline & Minimum & -2.06 & -2.27 & -5.67 & -3.41 \\
\hline & Maximum & 37.20 & 43.17 & 52.67 & 46.66 \\
\hline & Std. Deviation & 9.33 & 11.39 & 13.20 & 11.29 \\
\hline
\end{tabular}

Table 4:- Descriptive Statistics of ROA Data

Return on Assets (ROA) is the ratio between profit after tax and total assets. Descriptive data in the table is displayed as a percentage. Based on the table, the minimum value of ROA in 2015, 2016, 2017 and 2018 is owned by PT. Tri Banyan Tirta, Tbk., Each year there are companies that have the smallest ROA value compared to other companies. 
The maximum value of ROA in 2015 and 2018 is owned by PT Unilever Indonesia, Tbk., 2016 and 2017 is owned by PT. Multi Bintang Indonesia, Tbk ... Each year there are companies that have the highest ROA value compared to other companies.

The average DER variable of the consumer goods sector sampled in this study during 2015-2018 fluctuated and fluctuated within four years. The lowest average DER occurred in 2017 which was 7.48 and the highest average occurred in 2018 which was 0.89 .

\begin{tabular}{|c|c|c|c|c|c|}
\hline & Expan & 2015 & 2016 & 2017 & 2018 \\
\hline CR & The mean & 302.22 & 309.52 & 305.13 & 286.53 \\
\hline & Median & 218.97 & 232.85 & 240.72 & 265.97 \\
\hline & Minimum & 58.20 & 60.56 & 63.37 & 63.61 \\
\hline & Maximum & 927.65 & 831.82 & 863.78 & 728.18 \\
\hline $\begin{array}{c}\text { Std. } \\
\text { Deviation }\end{array}$ & 224.14 & 221.93 & 221.95 & 187.25 \\
\hline
\end{tabular}

Table 5:- Descriptive Statistics of CR Data

Current Ratio (CR) is a comparison between current assets and current debt. Descriptive data in the table is displayed as a percentage. Based on the table, the minimum value of CR in 2015 and 2018 is owned by PT. Multi Bintang Indonesia, Tbk., In 2016 and 2017 owned by PT. Unilever Indonesia, Tbk ... Each year there are companies that have the smallest CR value compared to other companies.

The maximum value of CR in 2015 and 2016 is owned by PT Industri Jamu and Pharmacy Sido Muncul, Tbk., In 2017 and 2018 owned by PT Delta Djakarta, Tbk ... Each year there are companies that have the highest $C R$ value compared to other companies.

\begin{tabular}{|c|c|c|c|c|c|}
\hline & Explan & 2015 & 2016 & 2017 & 2018 \\
\hline Asset & & & & 11.9 & \\
Growth & The mean & 9.67 & 10.37 & 2 & 7.24 \\
\hline & Median & 9.60 & 8.56 & 9.44 & 4.62 \\
\hline & & - & - & - & - \\
& Minimum & 10.46 & 10.52 & 4.78 & 5.72 \\
\hline & & & & 56.1 & 41.5 \\
& Maximum & 33.93 & 42.53 & 7 & 0 \\
\hline & Std. & & & 13.2 & \\
& Deviation & 11.51 & 10.85 & 4 & 9.80 \\
\hline
\end{tabular}

Table 6:- Descriptive Statistics of Asset Growth Data

Asset Growth (AG) is a comparison between assets this year and last year. Descriptive data in the table is displayed as a percentage. Based on the table, the minimum value of $A G$ in 2015, owned by PT. Merck, Tbk., In 2016 was owned by PT. Indofood Sukses Makmur, Tbk., In 2017 is owned by PT. Tri Banyan Tirta, Tbk., In 2018 was owned by PT Nippon Indosari Corpindo, Tbk. Each year there are companies that have the lowest AG value compared to other companies.

\section{Chow Test}

\begin{tabular}{|c|c|c|c|c|}
\hline \multicolumn{2}{|l|}{ Redundant Fixed Effects Tests } & & \\
\hline \multicolumn{2}{|c|}{ Equation: Untitled } & & \\
\hline \multicolumn{2}{|c|}{ Test cross-section fixed effects } & \\
\hline & & & & \\
\hline \multicolumn{2}{|c|}{ Effects Test } & Statistics & df & Prob. \\
\hline & & & & \\
\hline & & & \\
\hline \multicolumn{2}{c|}{ Cross-section F } & 4.202620 & $(19.5)$ & 0.0000 \\
\hline $\begin{array}{c}\text { Chi-square cross- } \\
\text { section }\end{array}$ & 70.895838 & 19 & 0.0000 \\
\hline
\end{tabular}

Table 7:- Chow Test Results

Chow test above that the Chi-square probability is 0,000 smaller than $\alpha$ (0.05), it can be concluded that HO is rejected and the Fixed Effecst model is more appropriate than the Common Effect model. When the selected model is Fixed Effects, it is necessary to do the next test, the Hausman Test.

\section{Hausman Test}

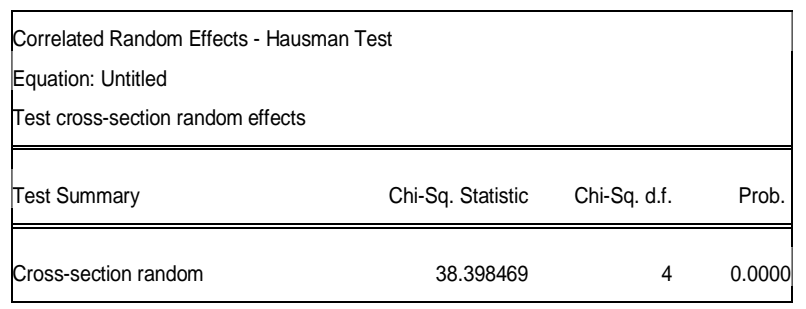

Fig 2

Chi-square Probability Value is 0.0000 less than 0.05). Then it can be concluded that HO is rejected, and the more appropriate model to use is the fixed effects model. Because the Hausman Test has chosen the fixed effects model, there is no need to do a Langrange Multiplier Test (LM Test).

\section{Hypothesis Testing Results}

\section{- Panel Data Regression Equation}

Based on the analysis used by using the evie 10 program, Panel Data Equation Regression with the Fixed Effects Method. then the regression equation can be written as follows:

$\checkmark$ Constant $C$ equal to shows that if the value of all independent variables, is constant $(0)$, then the value of the dependent variable Company Value or PBV $(Y)$ is equal to 1.704 .

$\checkmark$ The positive regression coefficient of the independent variable DER (X1) shows that DER has a positive relationship with the value of the consumer goods sector companies listed on the Indonesia Stock Exchange in 2015-2018. The regression coefficient is equal to every increase in DER of 1 unit, so the PBV or the value of the consumer goods sector company listed on the Indonesia Stock Exchange in 2015-2018 will 
increase by 1.6049 units. In this case other factors are considered permanent.

$\checkmark$ The positive regression coefficient of the independent variable ROA (X2) shows that ROA has a positive relationship with the value of the consumer goods sector companies listed on the Indonesia Stock Exchange in 2015-2018. The regression coefficient is equal to each increase in ROA of 1 unit, so the PBV or company value of the consumer goods sector listed on the Indonesia Stock Exchange in 2015-2018 will increase by 0.0793 units. In this case other factors are considered permanent.

$\checkmark$ The negative regression coefficient of the independent variable Current Ratio (X3) shows that the Current Ratio has a negative relationship to the value of the consumer goods sector companies listed on the Indonesia Stock Exchange in 2015-2018. The regression coefficient is equal to each increase in the Current Ratio of 1 percent, the PBV or the value of the consumer goods sector company listed on the Indonesia Stock Exchange in 2015-2018 will decrease by 0,0002 units. In this case other factors are considered permanent.

$\checkmark$ Positive regression coefficient for the independent variable Asset Growth (X4) shows that Asset Growth has a positive relationship with the value of the consumer goods sector companies listed on the Indonesia Stock Exchange in 2015-2018. The regression coefficient is equal to each increase in Asset Growth of 1 percent, the PBV or the value of the consumer goods sector company listed on the Indonesia Stock Exchange in 2015-2018 will increase by 0.0164 units. In this case other factors are considered permanent.

\section{- Tes Results $t$}

The $\mathrm{t}$ test results (partial regression test) can be explained:

$\checkmark$ The t-value of the independent variable X1 of 5.784 is greater $(>)$ than the t-table value of 1.645 , or the probability value of 0.0000 is smaller $(<)$ of $0.05(\alpha=$ $5 \%)$, then $\mathrm{H} 1$ is accepted That is, this shows that DER has a positive and significant effect on the value of consumer goods sector companies listed on the Indonesia Stock Exchange in 2015-2018, Accept Alternative Hypothesis 1 (Ha.1).

$\checkmark$ The t-count value of the independent variable X2 of 2.648 is greater $(>)$ than the t-table value of 1.645 , or the probability value of 0.0112 is smaller $(<)$ of $0.05(\alpha$ $=5 \%)$, then $\mathrm{H} 2$ is accepted That is, this shows that ROA has a positive and significant effect on the value of consumer goods sector companies listed on the Indonesia Stock Exchange in 2015-2018, Accept Alternative Hypothesis 2 (Ha.2).

$\checkmark$ The t-count value of the independent variable X3 of 0.3385 is smaller $(<)$ than the value of - t-table that is 1.645 , or the probability value of 0.7018 is greater $(>)$ of $0.05(\alpha=5 \%)$, then H3 is rejected. It means, this shows that $\mathrm{CR}$ has a negative and not significant effect on the value of the consumer goods sector companies listed on the Indonesia Stock Exchange in 2015-2018, Reject Alternative Hypothesis 3 (Ha.3).

$\checkmark$ T-value of independent variable X4 of 3.623 is greater $(>)$ than the value of t-table is 1.645 , or the probability value of 0.0008 is smaller $(<)$ of $0.05(\alpha=5 \%)$, then $\mathrm{H} 4$ is accepted That is, this shows that Asset Growth has a positive and significant effect on the value of consumer goods sector companies listed on the Indonesia Stock Exchange in 2015-2018, Accept Alternative Hypothesis 4 (Ha.4).

\section{- $\quad$ Test Results F}

The F test basically shows whether all independent or independent variables entered in the model have a joint influence on the dependent variable (Ghozali, 2011). The test has the following hypothesis:

HO: $\beta i=0$

Ha: at least one $\beta i \neq 0$

The results of the $F$ Test have been carried out in this study using eviews 10 program. By looking at the Fstatistic and Prob (F-statistic) it can be explained that the probability value of 0.0000 is smaller $(<)$ than 0.05 , meaning that this shows that the DER, ROA, CR and Asset Growth variables together significant effect on company value.

\section{- Determination Coefficient Test Results (R2)}

The coefficient of determination $R 2$ is a number that shows the magnitude of the proportion or percentage of the variation of the independent variable explained by the independent variable in the regression model see Adjusted $R$-squared can be explained that the value of the Determination Coefficient Test (R2) is equal to 0.954. That is, this shows that together DER, ROA, CR and Asset Growth variables have contributed to explain the value of the company by $95.4 \%$, while the remaining $4.6 \%$ is explained by other variables not examined or not included in this research model.

\section{DISCUSSION}

- Leverage as measured by Debt to Equity Ratio (DER) is proven to have a positive effect on Price to Book Value on Consumer Goods Sector Companies listed on the Indonesia Stock Exchange in the 2015-2018 period.

These results conclude that the level of DER will affect investors' considerations for investing. A high DER indicates that the company has more debt than the capital. Investors will consider investing in companies with a debt burden that is too large. Corporate debt to outsiders that is too large will affect the value of the company itself, so that it also affects the stock market price. This research is in line with research conducted by Safrida (2011), Riny (2018), Nugraheni (2015), Utomo (2016), Djamaludin (2018), Zuhroh (2019), Susanti (2018), Ayu, Bagus (2019), Markonah (2020), Ari (2017), Fajaria, Isnalita (2018), and contrary to research conducted by Rasyid (2015), Nasehah, Widyarti (2012), Timbuleng, Nangoy, Saerang (2015), Dewi, 
Return on Assets (ROA) has been proven to have a positive effect on Price to Book Value in Consumer Goods Sector Companies listed on the Indonesia Stock Exchange in the 2015-2018 period.

These results conclude that the higher the ROA, the company's ability to generate profits by managing its assets the better. Thus increasing the value of the company and the share price also rose. This research is in line with research conducted by Nugraheni (2015), Zuhroh (2019), Utomo (2016), Sabrin, Sarita Buyung, Takdir, Dedy (2016), Susanti, Restiana (2018), Ayu, Bagus, (2019), Markonah, Salim, Franciska (2020), Dwita, Rizqia, A., Aisjah, Sit., And Sumiati. 2013), Sucuahi, Cambarihan (2016), Suparno, Pitoyo (2016), Chen, Chen (2011), and contrary to research conducted by Triyani, Manhmudi, Rosyid (2018).

Curren Ratio $(C R)$ is proven to have no effect on Price to Book Value in the Consumer Goods Sector Companies listed on the Indonesia Stock Exchange in the 2015-2018 period.

These results conclude that the high or low ability of a company to meet its short-term obligations by utilizing its current assets does not affect the value of the company itself. This research is in line with research conducted by Markonah, Salim, Franciska (2020), Zuhroh (2019), Djamaludin, Maryadi, Marsum (2018), Timbuleng, Nangoy, Saerang (2015), Anjarwati, Chabachib, Demi (2016) and contradicting that carried out by Fajaria, Isnalita (2018), Data, Ari (2017), Riny (2018).

Asset growth is proven to affect the Price to Book Value of Consumer Goods Sector Companies listed on the Indonesia Stock Exchange in the 2015-2018 period.

These results conclude that the high and low growth of assets affect the value of the company or stock prices, and can be considered by investors in investing. This study is in line with research conducted by Safrida (2011), Nugraheni (2015), Officer, Wiksuana (2018), Data, Ari (2017), and contrary to research conducted by Nasehah, Widyarti (2012), Hutabarat, Fitrawaty, Nugrahadi (2018), Vidyanita, Hestinoviana, et al (2013), Fajaria, Isnalita (2018).

$>$ Debt to Equity Ratio (DER), Return on Assets (ROA), Curren Ratio, and Asset Growth together influence Price to Book Value in Consumer Goods Sector Companies listed on the Indonesia Stock Exchange in the 2015-2018 period.

This means that the independent variables affect the dependent variable.

\section{CONCLUSIONS,IMPLICATIONS AND RECOMMENDATIONS}

\section{A. Conclusion}

$>$ Leverage as measured by Debt to Equity Ratio (DER) has a positive and significant effect on Price to Book Value (PBV) in Consumer Goods Sector Companies that are listed on the Indonesia Stock Exchange in the 2015-2018 period.
Profitability as measured by Return on Assets (ROA) has a positive and significant effect on Price to Book Value on (PBV) Consumer Goods Sector Companies listed on the IDX for the 2015-2018 period.

$>$ Liquidity as measured by Curren Ratio (CR) is proven to have a negative and insignificant effect on Price to Book Value (PBV) of Consumer Goods Sector Companies listed on the Indonesia Stock Exchange in the 2015-2018 period.

> Asset Growth has a positive and significant effect on Price to Book Value (PBV) in the Consumer Goods Sector Companies listed on the Indonesia Stock Exchange in the 2015-2018 period.

\section{B. Suggestion}

$>$ For investors to pay attention to financial performance that can affect the value of the company such as DER, ROA, CR, and asset growth, because these variables can affect the value of the company (PBV).

$>$ For further research in order to add an independent variable in the form of other financial ratios that are possible to have a relationship with the value of the company .. For the dependent variable, can try to use other financial indicators such as Price Earning Ratio (PER), or market book ratio (MBR), or TOBINs Q. Likewise, the period and sample of the company should be added not only to the consumer goods sector, so as to obtain more optimal research results.

$>$ Future studies can also measure company value by other methods besides using panel data regression analysis. It aims to determine whether different methods of analysis will produce different or the same decision.

\section{REFERENCES}

[1]. Aggarwal D, Padhan PC, 2017. Impact of Capital Structure on Firm Value: Evidence from Indian Hospitality Industry. Theoretical Economics Letters 7: 982-1000.

[2]. Ajija, Shocrul R., et.al. Cara Cerdas Menguasai E Views, Salemba Empat, 2011.

[3]. Al, I. L. A. M., \& Nawaiseh. 2017. The impact of the financial performance of firm value: evidence from developing countries. International Journal of Applied Business and Economic Research, 15(16), 329-41.

[4]. Bangun, Nurainun, Wati, Sinta, 2007. Analisis Pengaruh Profitabilitas dan Kebijakan Dividen Terhadap Nilai Perusahaan Perdagangan, Jasa, dan Investasi, yang Terdaftar di Bursa Efek Idonesia, Jurnal Akuntansi, Tahun IX, no.2, pp. 107-120.

[5]. Budi, E.S, Rahmawati, EN 2014. "Analisis Pengaruh Return on Equity, Debt to Equity Ratio, Growth, dan Firm Size terhadap Price to Book Value pada Perusahaan Property dan Real Estate di Bursa Efek Idonesia", Jurnal Ekonomi, Manajemen, dan Akuntansi I, vol.22, no.1.

[6]. Chen, K. 2002. The Influence of Capital Structure on Company Value With Different Growth Opportunities, Paper for EFMA Annual Meeting, University of Lausanne. 
[7]. Djamaluin, Said, Maryadi, Marsoem, Bambang, 2016. The Effect of Fundamental Factor Against Price to Book Value on Building Contruction Sub Sector Companies in Indonesia Stock Exhange Period 20122016, International Journal of Innovative Research and Development, vol.7, issue 11, pp. 149-156.

[8]. Dwita, Rizqia, A., Aisjah, Sit., dan Sumiati. 2013. Effect of Managerial Ownership, Financial Leverage, Profitability, Firm Size, and Investment Opportunity on Dividend Policy and Firm Value. Research Journal of Finance and Accounting, Vol. 4, 120-130

[9]. Eka Lestari, Putu. 2010. Pengaruh Struktur Modal dan Kepemilikan Manajerial Serta Ukuran Perusahaan terhadap Nilai Perusahaan pada Perusahaan Manufaktur di Bursa Efek Idonesia. Skripsi Fakultas Ekonomi Universitas Udayana.

[10]. Gujarati, N. D \& Porter, D. C. 2013. Dasar-dasar Ekonometrika. Buku 1 dan Buku 2 Edisi 5. Penerjemah: Raden Carlus Mangunsong. Jakarta: Salemba Empat.

[11]. Keown, Martin, Pettyy, dan Scott, JR, 2005. Manajemen Keuangan Jilid 2 Edisi Kesembilan, Indeks. Jakarta

[12]. Laksono, Bagus. Analisis Pengaruh Return on Asset, Sales Growth, Pertumbuhan Aset, Cash Flow, dan Debt to Total Asset terhadap Dividend Payout Ratio (DPR) pada perusahaan yang listed di BEJ. Tesis. Universitas Diponegoro. (2006)

[13]. Lubis, IL, Sinaga, BM, Sasongko, Hendro, 2017. "Pengaruh Profitabilitas, Struktur Moal, dan Likuiditas Terhadap Nilai Perusahaan", Jurnal Aplikasi Bisnis dan Manajemen, vol. 3, no. 3, pp. 458465.

[14]. Mahendra Dj, Alfredo, Luh Gede Sri Artini, dan AA Gede Suarjaya. 2012. Pengaruh Kinerja Keuangan Terhadap Nilai Perusahaan Pada Perusahaan Manufaktur Di Bursa Efek Idonesia. Jurnal Manajemen, Strategi Bisnis, dan Kewirausahaan, 6(20, pp. 128-135, Denpasar: Fakultas Ekonomi Universitas Udayana.

[15]. Mahpudin, Endang, 2016. "Faktor-faktor yang Mempengaruhi Nilai Perusahaan (Studi Empiris Pada Perusahaan Manufaktur yang Terdaftar di Bursa Efek Idonesia”, JRKA, vol. 2, issue 2, pp. 56-75.

[16]. Mogdiliani, Miller, 1963. Corporate income taxes and the cost of corporate correction, Amrican Eonomics Review, vol. 53, pp. 443-453.

[17]. Myers, \& Brealey. (1991). Principles of Corporate Finance (4th ed.). WE

[18]. Noviyanto, Dwi. 2008. Pengaruh Rasio Profitabilitas dan Rasio investor terhadap Nilai Perusahaan pada Perusahaan LQ45 di Bursa Efek Jakarta tahun 20052007. Skripsi Universitas Negeri Malang.

[19]. Nugrahaeni, Novita, 2013. Faktor-faktor yang Mempengaruhi Nilai Perusahaan, Dividend Payout Ratio, Profitabilitas, dan Pertumbuhan Aset sebagai Variabel Intervening (Studi EMpiris Perusahaan Manufaktur di BEI)
[20]. Nurhayati, Mafizatun. 2013. Profitabilitas, Likuiditas, dan Ukuran Perusahaan Pengaruhnya Terhadap Kebijakan Dividen dan Nilai Perusahaan Sektor Non Jasa. Jurnal Keuangan dan Bisnis, 5(2), pp. 44-153

[21]. Nurmayasari, Andi, 2012. Analisis Pengaruh Profitabilitas, Ukuran Perusahaan, Leverage, dan Kebijakan Dividen terhadap Nilai Perusahaan (Studi Kasus pada Perusahaan Manufaktur di BEI Tahun 2007-2010). Skripsi Fakultas Ekonomi Universitas Islam Indonesia, Yogyakarta.

[22]. Rahayu, Maryati, Sari, Bida, 2018. "Faktor-faktor yang Mempengaruhi Nilai Perusahaan”, IKRAITHHUMANIORA, vol. 2, no. 2, pp. 69-76.

[23]. Riny, 2018. "Analisis Faktor-faktor yang mempengaruhi Nilai Perusahaan pada Perusahaan Consumer Goods Yang Terdaftar di Bursa Efek Idonesia”, JWM STI MIKROSKILL, vol. 8, no. 02, pp. 139-150.

[24]. Rompas, Gisela. 2013. Likuiditas, Solvabilitas, Dan Rentabilitas Terhadap Nilai Perusahaan BUMN yang Terdaftar Di Bursa Efek Idonesia. Jurnal EMBA, 1(3), pp. :252-262.

[25]. Sabrin, Sarita Buyung, Takdir, Dedy, Sujono, 2016. The Effect of Profitability on Firm Value in Manufacturing Company at Indonesia Stock Exchange, Th International Journal of Engineering and Science, vol. 5, Issue 10, pp. 81-89.

[26]. Safrida, Eli, "Pengaruh Struktur Modal, Pertumbuhan Perusahaan, Profitabilitas, dan Ukuran Perusahaan Terhadap Nilai Perusahaan" (Studi Pada Perusahaan Manufaktur di Indonesia), Jurnal Akuntansi Riset, Prodi Akuntansi UPI, vol.3, no.2, pp. 552-568.

[27]. Santoso, Yuswananre, Priantinah, Denies, 2016. "Pengaruh Profitabilitas, Ukuran Perusahaan, Struktur Aktiva, Likuiditas, dan Growth Opportunity Terhadap Struktur Modal Perusahaan", vol.4, no.4.

[28]. Sartono, Agus. 2010. Manajemen Keuangan Teori dan Aplikasi. Edisi ke 4. Yogyakarta: BPFE

[29]. Setiadharma, Machall, 2017. The Effect of Asset Structure and Firm Size on Firm Value with Capital Structure as Intervening Variable, Journal of Business and Financial Affairs, vol. 6, issu 4.

[30]. Shyam-Sunder \& Myers S. C. 1999. Testing Tradeoff against Pecking Order Models of Capital Structure. Journal of financial Economies. 51: 219-244.

[31]. Sidhu, M. K. (2018). Impact of Leverage of a Company on Stock Market Liquidity in Indian Markets, 20(1), 1-8. https://doi.org/10.9790/487X2001030108

[32]. Stephen A Ross, Randolph W. Westerfield, Bradford D. Jordan, Corporate Finance Fundamentals, Mc Graw Hill International Edition, 2008.

[33]. Sucuahi, W., \& Cambarihan, J. M. (2016). Influence of Profitability to the Firm Value of Diversified Companies in the Philippines. Accounting and Finance Research, 5(2). https://doi.org/10.5430/afr.v5n2p149

[34]. Sugiyono. 2012. Metodologi Penelitian Pendidikan Pendekatan Kuantitatif, Kualitatif, dan R \& D. Bandung: Alfabeta, Hal. 2. 
[35]. Sujoko, Soebiantoro. 2007. Pengaruh Kepemilikan Saham, Laverage, Faktor Intern dan Faktor Ektern Terhadap Nilai Perusahaan (Studi Emperik Pada Perusahaan Manufaktur di Bursa Efek Jakarta). Dalam Jurnal Manajemen dan Kewirausahaan, 9(1):h: 41-48.

[36]. Sukirni, Dwi. 2012. Kepemilikan Manajerial, Kepemilikan Institusional, Kebijakan Deviden dan Kebijakan Hutang Analisis Terhadap Nilai Perusahaan. Accounting Analysis Journal, 1(2).

[37]. Susanti, Neneng, Restiana, N.G., 2018. Whats the Best Factor to Determining Firm Value, Jurnal Keuangan dan Perbankan.

[38]. Sutrisno, 2016. Capital structure determinants and their impact on firm value: Evidence from Indonesia. Economics Word July-Aug, vol.4, no. 4, pp. 179-186.

[39]. Triyani, Wiwin, Mahmudi, Bambang, Rosyid, Abdul, 2018. "Pengaruh Pertumbuhan Aset Terhadap Nilai Perusahaan sebagai Variabel Intervening" (Studi Empiris pada Perusahaan Sektor Pertambangan yang Terdaftar di Bursa Efek Idonesia Tahun 2007-2016), Tirtayasa KONOMIKA, vol.1, no.1, pp. 107-129.

[40]. Utomo, NA, 2016. "Faktor-faktor yang Mempengaruhi Nilai Perusahaan pada Perusahaan Indeks LQ45 di Bursa Efek Idonesia”, Dinamika Akuntansi, Keuangan, dan Perbankan, vol. 5, no.1, pp. 82-94.

[41]. Utomo, Wawan, Anini, Rita, Raharjo, Kharis, 2016. "Pengaruh Leverage (DER), Pricee Book Value (PBV), Ukuran Perusahaan (Size), Return on Equity (ROE), Dividen Payout Ratio (DPR), dan Likuiditas (CR) Terhadap Price Earning Ratio (PER) pada Perusahaan Manufaktur yang Listing di BI tahun 2009-2014", Journal of Accounting, vol.2, no.2.

[42]. Wulandari, D.R., 2014. Pengaruh Profitabilitas, Operating Leverage, dan Likuiditas terhadap Nilai Perusahaan dengan Struktur Modal sebagai Intervening, Accounting Analisys Journal, pp. 26-55.

[43]. Wulandari, D.R., 2013. Pengaruh Profitabilitas, Operating Leverage, Likuiditas terhadap Nilai Peruahaan dengan Struktur Modal Sebagai Intervening, Jurnal Unnes, vol.2, no.4, pp. 455-463.

[44]. Zuhroh, Ida, 2019. The Effect of Liquidity, Firm Size, and Profitability on the Firm Value with Mediating Leverage, The 2nd International Conference on Islamic, Business, and Philantropy (ICIEBP) Theme: Sustainability and SocioEconomic Growth, vol. 2019. 